LUKASZ BARTOSIAK

Wydział Pedagogiczny

Uniwersytet Warszawski

ORCID ID: http://orcid.org/oooo-0oo2-4372-7571
Forum Pedagogiczne $2018 / 2$

Wpłynęło: 10.04.2018

Zatwierdzono do druku: 26.09.2018 DOI: 10.21697/fp.2018.2.12

\title{
ŹRÓDłA RELACJI OJCA Z DZIECKIEM W ŚRODOWISKU WIEJSKIM. KOMUNIKAT Z BADAŃ
}

\begin{abstract}
Streszczenie: Artykuł stanowi część projektu badawczego pt. Postawy ojcowskie w środowisku wiejskim. Poświęcony jest wąskiemu obszarowi projektu dotyczącemu źródeł warunkujących rodzaj relacji ojca z dzieckiem. Jakościowa analiza zebranego materiału badawczego, którą poprzedza teoretyczne wprowadzenie, dostarcza aktualnej wiedzy dotyczącej roli rodziny pochodzenia ojca oraz jego najbliższego otoczenia (koleżanki, koledzy, krewni) w pełnieniu własnego rodzicielstwa. Na jej podstawie wyodrębnione zostały trzy wizerunki rodzin, z których pochodzą badani mężczyźni oraz odpowiadające im zachowania i postępowania ojców wobec dzieci i pozostałych członków rodziny. Wyniki badań pokazują również, że rozmówcy w zdecydowanej większości nie posługują się wzorami zachowań ojcowskich obecnych w ich najbliższym środowisku życia.
\end{abstract}

Słowa kluczowe: ojciec, dziecko, rodzina, opieka, wychowanie.

\section{Wprowadzenie}

W myśl społeczno-poznawczej teorii osobowości Juliana B. Rottera, zachowanie ludzi z najbliższego otoczenia człowieka (wzmocnienie społeczne) determinuje w bardzo dużym stopniu zachowanie jednostki (ojca w życiu rodzinnym). Problematyka niniejszego artykułu uzasadnia odniesienie się do doświadczeń z przeszłości - z rodzin pochodzenia badanych ojców, na co zwraca uwagę J. B. Rotter. Zdaniem autora, charakteryzując osobowość człowieka, nie można pominąć jego przeszłości, która w największym stopniu go ukształtowała (Sosnowski 2011). Maria Tyszkowa dodaje, że poznanie przeszłości jednostki pozwala przewidywać jej przyszłe zachowania (1988). W kontekście podjętego tematu ważne jest poznanie zachowań oraz relacji ojciec-dziecko-matka, które w życiu badanych mężczyzn prezentowali ich ojcowie. W konsekwencji pozwoli to na uzyskanie odpowiedzi na pytanie, czy doświadczenia wyniesione przez badanych $\mathrm{z}$ rodziny pochodzenia, związane $\mathrm{z}$ relacjami wewnątrzrodzinnymi (w sposób szczególny z ich ojcami), mają wpływ na ich obecne 
relacje z własnymi dziećmi. Artykuł jest częścią szerszego projektu badawczego pt. Postawy ojcowskie $w$ środowisku wiejskim. Poza wiedzą teoretyczną dotyczącą ojcostwa i postaw, operacjonalizacją przyjętych do analizy pojęć, znajdziemy w nim m.in. obecny stan wiedzy i dorobek naukowy podjętej problematyki, opis wybranych teorii wyjaśniających zachowania ojcowskie czy szeroko rozumiany udział ojca w procesie opieki i wychowania dziecka. W projekcie stworzyłem własną typologię postaw ojcowskich oraz określiłem modele ojcostwa w badanych rodzinach.

Badania prezentowane w niniejszym artykule, oparte na metodologii jakościowej, przeprowadzone zostały w 19 wylosowanych wsiach powiatu płockiego (Bończa, Łaziska, Piotrkówek, Słubice, Grabowiec, Słupno, Ciółkowo, Śmiłowo, Wyszyna, Dobrzyków, Orszymowo, Dzierżanowo, Cieszewo, Czermno, Kamień Polski, Gąbin, Kobylniki, Rębowo, Soczewka). Wybrana orientacja metodologiczna umożliwiła mi jakościowy opis i analizę badanych zjawisk, ich porównanie i ustalenie siły związków między nimi lub też występujących między nimi różnic. Analiza jakościowa dała również możliwość określenia i zdefiniowania uczuć, jakie przeżywają ojcowie w stosunku do dziecka, czynników, które różnicują te uczucia, rodzajów emocji towarzyszących komunikowaniu się z dzieckiem czy też wewnętrznego ustosunkowania się mężczyzn do swej roli ojcowskiej. Mogłem także określić przeżycia ojców, wszelkie zachowania wobec członków rodziny poprzez odwołanie się do ich subiektywnych odczuć, doświadczeń, przeżyć oraz poznać i opisać wiele zjawisk związanych ze współczesnym ojcostwem. W celu pozyskania interesującego mnie materiału badawczego posłużyłem się techniką wywiadu pogłębionego. Uznałem, że indywidualne wywiady pogłębione, a następnie jakościowa analiza treści wypowiedzi respondentów w najlepszy sposób pozwolą opisać i zrozumieć badany fragment rzeczywistości społecznej. Narzędziem badawczym był stworzony przeze mnie scenariusz wywiadu. W badaniu wzięło udział 37 respondentów (ośmiu posiada wykształcenie wyższe, 18 - średnie, dziewięciu - zasadnicze oraz dwóch - podstawowe). Ich celem było określenie postaw ojcowskich w środowisku wiejskim. Nie spełniają one cech reprezentatywności. Zebrany materiał badawczy pogłębia wiedzę o istocie danego zjawiska, nie zaś o jego zakresie społecznym. Dane uzyskane podczas analizy zestawiane były ze sobą w odniesieniu do wielu koncepcji, które w sposób naukowy wyjaśniają prawidłowości związane z zachowaniem i funkcjonowaniem mężczyzny w roli ojca oraz jego postawami. Pod uwagę wzięta została społeczno-uczeniowa teoria osobowości J. Rottera (Gładowa 1999), teoria ekologii humanistycznej Urie Bronfenbrennera (Sosnowski 2011), społeczno-poznawcza teoria Alberta Bandury (Gładowa 1999), a także stanowiąca najważniejsze odniesienie teoretyczne dla podjętej problematyki - poznawcza koncepcja postaw autorstwa Davida Crecha, Richarda S. Crutchfielda, Egertona L. Ballacheya (Mądrzycki 1970). Badanie obejmowało wiele zagadnień. Niniejszy artykuł poświęcony jest wąskiemu ich fragmentowi dotyczącemu źródeł warunkujących rodzaj relacji ojca $\mathrm{z}$ dzieckiem. Zgodnie $\mathrm{z}$ metodologicznymi założeniami dobór próby miał charakter celowy. Następujące cechy stanowiły kryteria doboru celowego: 
- ojcowie mający dziecko w klasie I-III szkoły podstawowej z terenu powiatu płockiego (teren wiejski);

- wiek ojców: badani mężczyźni nie mogli mieć więcej niż 40 lat;

- $\quad$ wiejskie gminy powiatu płockiego - losowanie szkół, do których uczęszczają dzieci badanych ojców;

- miejsce zamieszkania: badani ojcowie mieszkają na wsi.

Zagadnienie dotyczące źródeł warunkujących rodzaj relacji badanych ojców z ich dziećmi stanowiło jedno z wielu problemów szczegółowych, które zostały sprecyzowane w celu znalezienia odpowiedzi na główny problem badawczy projektu - jakie są współczesne postawy ojcowskie w rodzinach wiejskich oraz jakie czynniki je warunkują?

\section{Rodzina pochodzenia jako źródło warunkujące postawy badanych}

Obraz rodziny pochodzenia badanych ojców, jaki wyłania się z ich opisów, zawiera zróżnicowaną treść i zabarwienie emocjonalne. Badania pokazują, że jedynie dwóch rozmówców bardzo dobrze wspomina relacje z własnym ojcem. Pozostałych 28 określa je jako dobre, raczej dobre lub średnie, zaś siedmioro uważa je za bardzo złe. To wiedza skłaniająca do wielu wniosków i refleksji. Badani, którzy relacje z własnym ojcem wspominają bardzo dobrze, podkreślają, że ojciec jest dla nich wzorem postępowania, opieki i wychowania swoich dzieci. W myśl ich deklaracji, starają się naśladować ojca oraz żyć w zgodzie z wpojonymi przez niego wartościami i postawami. Są z tego powodu bardzo szczęśliwi i przekazują dzieciom wszystko to, co przekazał im ich ojciec. Wszelkie relacje ojciec-dziecko-matka, zapamiętane z dzieciństwa, są źródłem obecnych relacji w rodzinach tych respondentów. Podkreślają przede wszystkim zapamiętane wzory zachowań ojców oraz stosowane przez nich metody wychowawcze, czego następstwem tego są określone działania wychowawcze podejmowane obecnie w stosunku do własnych dzieci. Ojcowie ci są przekonani o wartości metod wychowawczych stosowanych w domu rodzinnym i wierzą, że przyniosą one określone pozytywne następstwa ich działań pedagogicznych. Badani mężczyźni wspominają swoich ojców jako osoby kochające, opiekuńcze, potrafiące zadbać o rodzinę, dbające o bezpieczeństwo materialne, bliskość emocjonalną i spokój w rodzinie. Wśród cech swoich ojców wymieniają także przejawianą w określonych sytuacjach surowość, którą także zaliczają do pozytywnej strony ich osobowości. Ponadto wspominają swoich ojców jako osobę interesującą się szkołą, osiągnięciami dziecka w nauce, pomagającą mu w odrabianiu prac domowych oraz poświęcającą dziecku możliwie dużo czasu. Jeden z tej grupy badanych twierdzi wręcz, że ojciec spędzał z nim więcej czasu niż obecnie on spędza ze swoim dzieckiem. Co ciekawe, obaj badani mężczyźni przypominają sobie, że osobą mającą większy udział w wychowaniu i opiece nad dzieckiem w rodzinach ich pochodzenia była matka. Twierdzą, że to głównie do niej należały czynności opiekuńcze, również ona miała decydujący głos, jeśli chodzi o podjęcie 
różnych decyzji wychowawczych dotyczących dziecka. Mimo deklarowanych dobrych stosunków pomiędzy poszczególnymi członkami rodziny pochodzenia, może to świadczyć o istniejącym wówczas dość sztywnym i ustalonym podziale obowiązków rodzinnych na męskie i kobiece. Niezależnie od dobrych wspomnień dotyczących własnych ojców, mężczyźni pamiętają, że ich ojcowie dużo pracowali, aby zapewnić rodzinie możliwie najlepsze warunki materialne. Obaj mężczyźni uważają, że wraz z rodzeństwem byli traktowani przez ojców sprawiedliwie, nikt nie był faworyzowany $i$ traktowany odmiennie. Badani odnoszą wrażenie, że mimo wszystko bardziej związani byli z matkami, dodają jednak, że do swoich ojców mogli udać się z każdym problemem oraz prośbą o różnoraką pomoc. Twierdzą, że ich ojcowie raczej nie stosowali nagród i kar. Rozmówcy nie przypominają sobie, żeby kiedykolwiek byli przez ojca ukarani czy też szczególnie nagrodzeni. Są bardzo dumni ze swoich ojców oraz wdzięczni za dobre wychowanie, o czym świadczą chociażby takie słowa: „Przede wszystkim jestem wdzięczny za miłość, którą mnie obdarzył [...]. Zawsze mogłem na tacie polegać i tak jest do dziś [...]. Nigdy mnie nie zawiódł, właściwie do dziś dnia dużo nam pomaga, a jeśli chodzi o opiekę nad dziewczynami nigdy nie ma kłopotu. Dzwonię do taty i tato jest. Naprawdę rzadko mi odmawia. Za to go kocham i szanuję, że zawsze mogłem na nim polegać, że wiedziałem, że jak do niego pójdę, to on mi pomoże" (36 lat, nauczyciel, wykształcenie wyższe, dwoje dzieci). Ojcowie ci podkreślają, że nie mają do swojego ojca żadnych uwag ani żalu: „ojciec do dziś dnia robi wszystko, żebyśmy mieli lepiej i łatwiej, i uważam, że jako tata się spełnił, a ja, jako tata, absolutnie nie wyobrażam sobie, że mógłbym coś mojemu tacie zarzucić, że czegoś mi nie wytłumaczył, czegoś nie przekazał. Myślę, że jako tata się spełnił i wdzięczny jestem mu za to" (37 lat, nauczyciel, wykształcenie wyższe, dwoje dzieci).

Badania sugerują, że taki wizerunek rodziny pochodzenia badanych może być źródłem prawidłowych postaw ojcowskich w rodzinach wiejskich. Analiza zebranego materiału badawczego pokazuje ponadto, że doświadczenia wyniesione przez badanych $\mathrm{z}$ domu rodzinnego, związane $\mathrm{z}$ relacjami zachodzącymi zwłaszcza z własnymi ojcami, wpływają na ich obecne relacje z dziećmi. Jak wcześniej wspomniałem, 28 badanych wspomina relacje ze swoim ojcem jako dobre, raczej dobre lub średnie. Mężczyźni ci w przeważającej większości uważają, że ich ojcowie mało interesowali się dziećmi i ich wychowaniem. Mimo wymienianych wielu pozytywnych cech swoich ojców, najczęściej takich jak: kochający, opiekuńczy, twierdzą, że ich ojcowie byli bardzo surowi, porywczy, nadmiernie kontrolujący i szybko zmieniający zdanie, co było przyczyną wielu nieporozumień i kłótni rodzinnych. Przedstawiciele tej grupy badanych dodają, że ich ojcowie byli osobami nadmiernie wymagającymi oraz bardzo często stosującymi kary wobec dzieci, najczęściej kary cielesne. Na zjawisko takie wskazuje chociażby następująca wypowiedź: „Ojciec był tylko od karania. Ja, w szczególności teraz, gdy mam swoje dzieci, w ogóle takich zasad nie stosuję" (39 lat, rolnik, wykształcenie podstawowe, dwoje dzieci). Bardzo rzadko rozmówcy przypominają sobie jakiekolwiek nagrody 
od swoich ojców, np. za dobre wyniki w nauce, pomoc w gospodarstwie czy dobre zachowanie. $Z$ wypowiedzi tej, podobnie jak $\mathrm{z}$ wielu innych, wynika, że badani, mimo że ich relacje $\mathrm{z}$ własnym ojcem określają jako raczej dobre, nie biorą z niego przykładu oraz nie stanowią one źródła obecnych relacji w badanych rodzinach. W większości przypadków ojcowie przywoływanych tu rozmówców nie są wzorem postępowania, opieki i wychowania dziecka, o czym świadczą następujące słowa: „Ojciec pracował jako murarz, często wyjeżdżał, jako autorytet dla mnie nie istniał, nie było czegoś takiego. U nas była tylko mama, ciągle mama. Mama była nauczycielką, mama była na miejscu, a ojciec też często nadużywał alkoholu [...]. Wielkiego wpływu nie miał" (39 lat, policjant, wykształcenie wyższe, dwoje dzieci). Wszyscy mężczyźni deklarują większe przywiązanie do matki.

Badania podkreślają istnienie wyraźnego podziału obowiązków pomiędzy rodzicami, w rodzinach, $w$ których jeden z rodziców większość czynności związanych z dzieckiem przypisywał matce. Respondenci deklarują, że ich ojcowie bardzo mało lub też $\mathrm{w}$ wielu przypadkach w ogóle nie interesowali się ich nauką, szkołą, nie pomagali im w odrabianiu prac domowych, a także nie przyczyniali się w jakikolwiek sposób do rozwoju ich zainteresowań. Jak twierdzą, byli ojcami bardzo chłodnymi i oziębłymi, dla których priorytetem była praca. Możemy jedynie przypuszczać, że takie postępowanie oraz system wartości spowodowany był $\mathrm{w}$ wielu przypadkach istotą czasów, w których rola ojca ograniczała się jedynie do zapewnienia rodzinie bytu materialnego. Pracowitość to jedna $\mathrm{z}$ niewielu cech, którą respondenci przypisują swoim ojcom, jako tę pozytywną, przyczyniającą się do zapewnienia materialnego bezpieczeństwa rodzinie. Badani mężczyźni sugerują, że ich ojcowie bardzo często faworyzowali swoje dzieci, najczęściej najmłodsze dziecko lub synów. Mogło to oznaczać postrzeganie potomka płci męskiej jako osoby mogącej mieć podobne do ojca zainteresowania, a w konsekwencji spadkobiercy gospodarstwa. Należy nadmienić, że prawie wszyscy ojcowie badanych mężczyzn byli rolnikami i posiadali własne gospodarstwa. Wśród wielu złych zachowań i postaw własnego ojca znajdują oni także te, które uważają za słuszne, np. wspomniany już szacunek do pracy. Starają się je przekazywać swoim dzieciom. Najczęściej jednak badani mężczyźni deklarują, że doświadczenia, które pamiętają z rodzin swojego pochodzenia, są dla nich źródłem wiedzy mówiącej, jak nie należy postępować wobec własnego dziecka. Siedmiu badanych określa relacje z własnym ojcem jako bardzo złe, sugerując wręcz, że dobrych relacji nie było. Wspominają oni swoich ojców jako osoby nadużywające alkoholu, stosujące różne formy agresji i przemocy w stosunku do nich oraz ich matek oraz w ogóle nieinteresujące się dzieckiem: „Ojciec był i jest alkoholikiem. Relacje były takie, że w domu ciągle były awantury. Między innymi właśnie dlatego nie piję, żeby dzieci moje nie miały tego, co ja miałem" (40 lat, budowlaniec, wykształcenie średnie, troje dzieci).

Wypowiedzi takie świadczą o tym, że ojciec nie jest dla nich żadnym przykładem ani wzorem postaw i zachowań. Rozmówcy, mimo że chętnie dzielą się z badaczem przykrymi wspomnieniami, bardzo często mają łzy w oczach, tak jak mężczyzna 
wypowiadający te słowa: „Mój ojciec nadmiernie nadużywał alkoholu. Nie widziałem w nim ojca, nie widziałem przyjaciela, nie widziałem kolegi, wychowywała mnie matka i babcia [...]. Ojciec nigdy nie interesował się tym, jak się uczę, jeszcze bardziej krzyczał i dostawałem nie przysłowiowego klapsa tylko lanie pasem. Jeśli chodzi o to, chciałem być inny w wychowaniu swojego dziecka. Powiedziałem sobie, że będę zupełnie odmienny" (39 lat, logistyk, wykształcenie średnie, dwoje dzieci). Wszystkie wypowiedzi badanych, którzy swoje relacje z własnym ojcem wspominają jako bardzo złe, są bardzo do siebie podobne. Respondenci mówią, że ojciec nie wykonywał przy nich żadnych czynności opiekuńczych oraz nie interesował się w najmniejszym stopniu ich życiem.

Rodzina, w której nadużywany jest alkohol, nie zapewnia dziecku poczucia bezpieczeństwa i stabilizacji emocjonalnej. Taka sytuacja w życiu dziecka prowadzi często do głębokich urazów psychicznych, powodujących zmiany w strukturze osobowości, problemy emocjonalne i zaburzenia w zachowaniu (Ryś 1998). Negatywny obraz rodziny pochodzenia może mieć wpływ na postawy ojcowskie badanych w ich dorosłym życiu, może stanowić źródło określonych negatywnych zachowań w stosunku do dzieci w procesie wychowania (stosowanie kar, przemoc, nieumiejętność przekazywania uczuć, chłód emocjonalny, zerwane więzi emocjonalne, niewłaściwe zachowania itp.). Jednakże badania pokazują, że takie wspomnienia i wyłaniające się z nich obrazy rodziny pochodzenia badanych ojców nie wywarły negatywnego wpływu na ich zachowania w dorosłym życiu. Przeciwnie - wszyscy badani, którzy relacje $z$ własnym ojcem określają jako bardzo złe, starają się postępować odwrotnie. Jak twierdzą, wyciągnęli wnioski z dzieciństwa i czynią wszystko, aby ich dzieci nie doświadczały ze strony ojca złych zachowań. Oto wypowiedź mężczyzny, którego rodzice rozwiedli się z powodu nadużywania przez ojca alkoholu: „Doświadczenia związane z zachowaniami ojca determinują mnie do tego, żeby zachowywać się zupełnie inaczej, naprzeciw biegunowo do jego zachowania. Jak najbardziej relacje z moim ojcem wpływają na relacje moje $\mathrm{z}$ własnymi dziećmi. Wiem, co może spotkać moich najbliższych, gdy będę postępował tak jak on. Także są dla mnie taką przestrogą i mam taki bat nad sobą, że tak i tak nie wolno postępować, bo wiem, do czego to doprowadzi, jakie będą tego skutki. Także staram się nie brać z niego przykładu, tylko działać zupełnie naprzeciw jego zachowaniu” (32 lat, instruktor pływania, wykształcenie wyższe, troje dzieci). Jeden mężczyzna spośród omawianej tu grupy badanych twierdzi, że jego relacje z własnym ojcem były tak złe, że nie chce o nich wspominać: „Te relacje to katastrofa i porażka. Lepiej bym nie chciał rozmawiać na ten temat" (39 lat, właściciel firmy, dwoje dzieci). Mimo wszystko rozmówca zdecydował się przybliżyć obraz rodziny, z której pochodzi. Można paradoksalnie stwierdzić, że negatywne zachowania ojca i jego postawy pozytywnie wpłynęły na ojcostwo badanych mężczyzn. Badani deklarują, że wyciągają wnioski z młodych lat, starając się postępować zupełnie inaczej, niż czynił to ich ojciec. Ich obecne postawy są również wyrazem emocjonalnej dojrzałości oraz systemu wartości, 


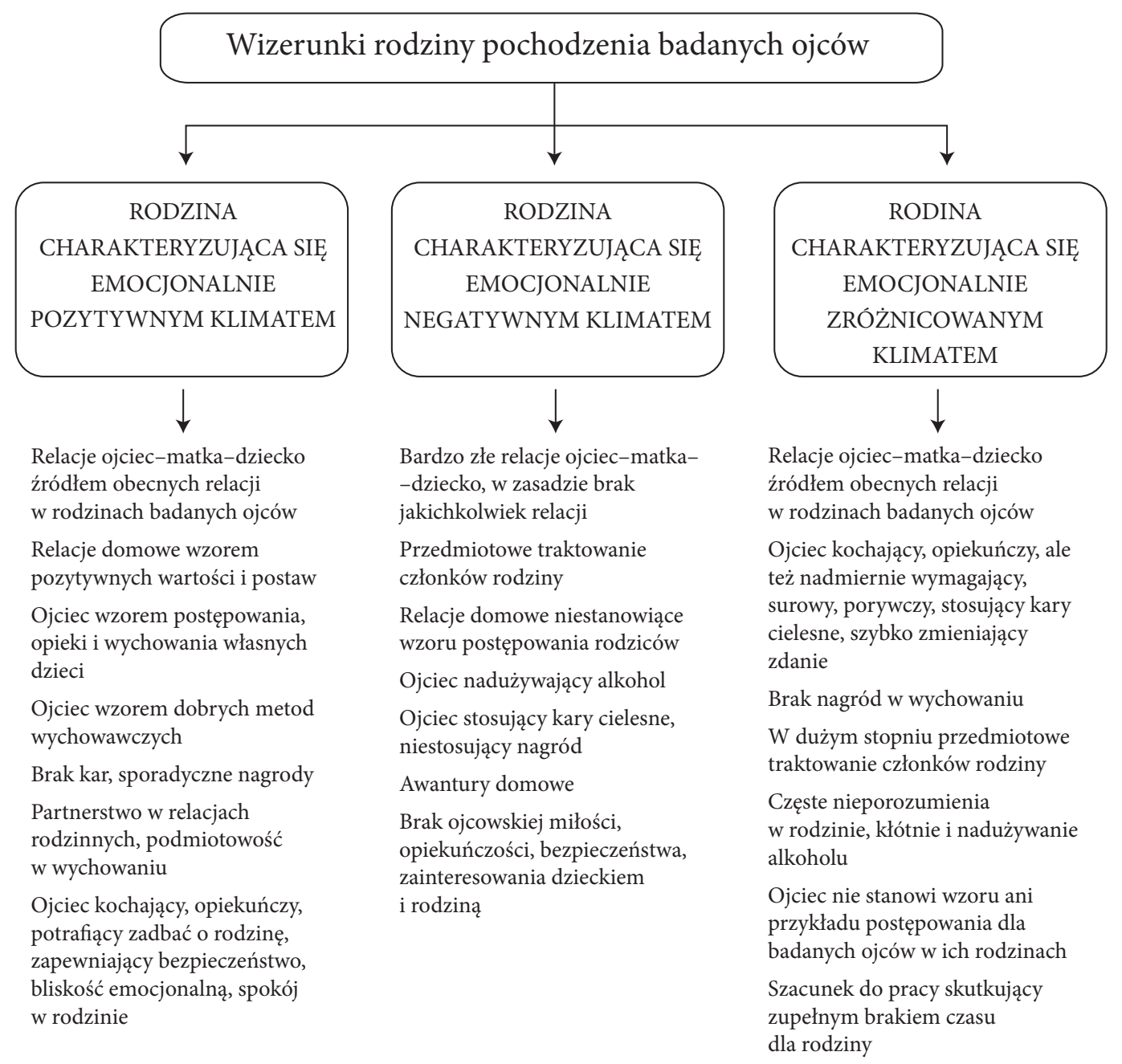

Rys. 1. Wizerunki rodziny pochodzenia badanych ojców

w którym rodzina plasuje się na pierwszym miejscu. Deklarują, że starają się stworzyć własnym dzieciom lepsze warunki rozwoju, niż te, które mieli sami w przeszłości. Można sądzić, że mężczyźni mający świadomość, że wychowanie realizowane przez ich ojców było złe, chcą stworzyć inny model wychowania we własnych rodzinach, chcąc tym samym uniknąć powtarzania błędów swoich ojców. Wyniki badań pokazują, że mimo złych doświadczeń wyniesionych z rodziny pochodzenia, taki scenariusz im się udaje. Wielu badanych zwraca również uwagę, że obecne czasy nie pozwoliłyby na wykorzystywanie doświadczeń wyniesionych $\mathrm{z}$ ich domu rodzinnego. Ich zdaniem zmiany ustrojowe oraz postęp cywilizacyjny pociągają za sobą także zmiany w działaniach wychowawczych realizowanych przez współczesnych rodziców.

Analiza zebranego materiału badawczego pokazuje, że mamy do czynienia z trzema obrazami rodzin, z których pochodzą badani mężczyźni: 
- obraz rodziny pochodzenia o zabarwieniu emocjonalnym pozytywnym, sugerujący, że badani ojcowie chętnie wracają do wspomnień z dzieciństwa i wykorzystują zapamiętane zachowania własnych ojców w procesie wychowania własnych dzieci;

- obraz rodziny pochodzenia o zabarwieniu emocjonalnym negatywnym, sugerujący, że badani ojcowie niechętnie wracają do wspomnień z dzieciństwa oraz relacji z własnym ojcem, wyciągając jednocześnie wnioski z jego postępowania i starając się eliminować je ze swojego życia, postępując odwrotnie;

- obraz rodziny pochodzenia o zabarwieniu emocjonalnym zróżnicowanym, sugerujący, że badani ojcowie dość chętnie wracają do wspomnień z dzieciństwa i relacji z własnym ojcem, oceniając je raczej dobrze, jednak dostrzegają w jego postępowaniu wiele negatywnych aspektów, które sprawiają, że ojciec raczej nie jest dla nich wzorem postaw i zachowań wobec własnych dzieci.

Schemat umieszczony na poprzedniej stronie przedstawia wymienione obrazy rodzin oraz odpowiadające im zachowania i postępowanie ojców wobec dzieci i pozostałych członków rodziny.

\section{Najbliższe środowisko życia badanych (koleżanki, koledzy, krewni) jako czynnik warunkujący postawy ojcowskie}

Zgodnie z przyjętą (jako podstawę teoretyczną prowadzonych analiz) w pracy teorią symbolicznego interakcjonizmu (Sztompka 2006) zakładam, że na zachowanie jednostki ma wpływ rzeczywistość społeczna, pod którą kryje się wiele interakcji zachodzących między jej uczestnikami. Są one źródłem wizji własnej osoby (ojca), która kształtuje się na podstawie reakcji partnerów (koleżanki i koledzy z pracy, bliscy znajomy, krewni) i zachodzących między nimi interakcji. Zgodnie z tymi założeniami ojciec w rodzinie, mający świadomość, że jest dobrym ojcem (co potwierdza żona, dziecko i jego najbliższe otoczenie), łatwiej podejmuje kolejne działania rodzicielskie, zwiększa szansę ich powodzenia oraz ma wyższe poczucie spełnienia własnej roli w rodzinie. Ważne jest w związku z tym poznanie, w jaki sposób najbliższe środowisko życia badanych wpływa na ich codzienne zachowania, na postawy i pełnione role męża i ojca. Istotne jest również odwołanie się w tym miejscu do wybranych założeń społeczno-poznawczej teorii A. Bandury, która przedstawia mechanizm modelowania, jako proces obserwacji i uczenia się przez ojców nowych wzorów zachowań istniejących w ich najbliższym środowisku życia (koleżanki i koledzy z pracy, bliscy znajomy, krewni) (Gładowa 1999).

Analiza zebranego materiału badawczego pokazuje, że respondenci na temat dzieci rozmawiają z koleżankami i kolegami oraz z bliskimi krewnymi - członkami rodziny. Bliscy krewni (najczęściej rodzeństwo z rodziną) są najczęstszymi partnerami rozmów, z którymi porusza się tę problematykę. Nieco rzadziej badani ojcowie rozmawiają o dzieciach z koleżankami, kolegami i znajomymi. Dwóch rozmówców wymienia także sąsiadów, jako osoby, z którymi zdarzyło się podczas 
prac podwórkowych rozmawiać na temat dzieci. Rozmowy z krewnymi odbywają się najczęściej podczas rodzinnych spotkań z okazji różnorodnych świąt, wspólnych obiadów niedzielnych u rodziców badanych oraz w okolicznościach nieplanowanych spotkań przy kawie. Badania ukazują, że wymiana poglądów z koleżankami i kolegami odbywa się zwykle w miejscu pracy rozmówców. Można w związku z tym wnioskować, że badani uważają swoich kolegów i koleżanki, z którymi pracują na co dzień zawodowo, za osoby, którym można zaufać. Może to świadczyć także o dobrych relacjach pomiędzy nimi, otwartości i priorytetowym traktowaniu wszelkich tematów wychowawczych. Pięciu respondentów deklaruje, że takie rozmowy prowadzi bardzo często, 29 przyznaje, że zdarza im się rozmawiać na tematy dotyczące dzieci, zaś trzech badanych nigdy z nikim nie rozmawiało o dzieciach oraz nie mają w planach wymiany poglądów dotyczących tej problematyki.

$Z$ badań wynika też, że respondenci niechętnie wypowiadają się o innych, znanych im ojcach $z$ najbliższego toczenia, pełnionej przez nich roli oraz postawach wobec dziecka. Zapewne dzieje się tak dlatego, ponieważ mimo korzystania przez znaczną liczbę badanych z możliwości kontaktu z innymi ojcami podczas wykonywania obowiązków zawodowych, nie znają oni bliżej ich zachowań ojcowskich. Powtarzające się u ponad połowy respondentów sformułowanie typu: „myślę, że są dobrymi ojcami” potwierdzają powyższą tezę. Jedenastu spośród wszystkich badanych deklaruje, że nie o wszystkich swoich znajomych mogą wyrazić pochlebne słowa. Przyznają, że jest wśród nich wielu, co do których mają sporo zastrzeżeń, w postępowaniu których należałoby wiele zmienić. W większości przypadków chodzi tutaj o nadużywanie alkoholu oraz małe zainteresowanie rodziną. Jedynie pięciu rozmówców upatruje w postępowaniu swoich znajomych wiele pozytywnych aspektów, takich jak troska o dzieci i rodzinę, zaradność, uczuciowość, system wartości i priorytety życiowe, zaangażowanie w organizowanie dzieciom czasu wolnego i ogólne zainteresowanie sprawami dziecka, biorąc jednocześnie z nich przykład. Zauważa się jednak, że stanowisko takie wyrażają respondenci pracujący głównie w rolnictwie i posiadający więcej niż jedno dziecko. Można przypuszczać, że w rodzinach wychowujących więcej niż jedno dziecko mężczyźni przez fakt zaangażowania ich $\mathrm{w}$ wychowanie rodzinne oraz zdobyte doświadczenie, posiadają większą umiejętność dostrzegania pozytywnych i negatywnych zachowań ojcowskich, starając się skupiać uwagę na tych pożądanych, aby móc wykorzystać je we własnych rodzinach. $Z$ drugiej jednak strony należy wziąć pod uwagę, że rolnicy nie spotykają się ze swoimi znajomymi, np. w zakładzie pracy, co rodzi obawy dotyczące prawdziwości ich stwierdzeń. Brak zależności pomiędzy wyrażaniem prezentowanych opinii na temat ojcostwa swoich znajomych bądź krewnych a wykształceniem badanych może świadczyć o tym, że czynnik ten nie wpływa na oceny obserwowanych zachowań ojcowskich. 


\section{Podsumowanie}

Badania ukazały, że respondenci w zdecydowanej większości nie naśladują zachowań swoich kolegów z pracy oraz krewnych, nie chcą tym samym posługiwać się wzorami zachowań ojcowskich obecnych w ich najbliższym środowisku życia. Ojcowie mają własne wypracowane metody wychowawcze, co sprawia, że nie potrzebują wzorować swojego ojcostwa na innych rodzinach. Sytuacja taka spowodowana może być zarówno słabą znajomością zachowań ojcowskich osób z najbliższego otoczenia badanych, o czym wspomniano wcześniej, jak też wewnętrznym przekonaniem o negatywnych zachowaniach wielu ojców wobec dzieci, których przesłanką może być zauważany przez badanych problem alkoholowy, utrudniający w ich przekonaniu realizację funkcji ojcowskich. Być może z tego powodu ojcowie nie chcą powtarzać takich zachowań. Słaba wiedza o tym, jak koledzy, znajomi lub krewni postępują wobec własnych dzieci, może również wzbudzać niepokój, gdyż ukazuje współczesny problem wielu rodzin związany z izolowaniem się rodziny od społeczności lokalnej (Tyszka 2002). Jak widać, badani są w stanie dokonać właściwej oceny zachowań ojcowskich innych ojców i nie przyjmować ich jako wzory do naśladowania. Analiza zebranego materiału badawczego pokazała również, że badani ojcowie w większości przypadków źle wspominają relacje z własnym ojcem i nie naśladują jego zachowań we własnych rodzinach. Starają się, aby proces opieki i wychowania ich dzieci oraz relacje wewnątrzrodzinne były zupełnie odwrotne. Nie nadużywają alkoholu, spędzają z dziećmi czas, chcą uczestniczyć możliwie często w ich życiu oraz stanowić dla nich wzór postępowania.

\section{Bibliografia}

Gładowa A. (red.). (1999). Klasyczne i współczesne koncepcje osobowości. Kraków: Wydawnictwo Uniwersytetu Jagiellońskiego.

Mądrzycki T. (1970). Psychologiczne prawidłowości kształtowania się postaw. Warszawa: Wydawnictwa Szkolne i Pedagogiczne.

Ryś M. (1998). Rodzina z problemem alkoholowym jako rodzina dysfunkcyjna, „Studia nad Rodziną”, nr 2, s. 71.

Sosnowski T. (2011). Ojciec we współczesnej rodzinie - kontekst pedagogiczny. Warszawa: Wydawnictwo Akademickie Żak.

Sztompka T. (2006). Socjologia. Analiza społeczeństwa. Kraków: Wydawnictwo „Znak”.

Tyszkowa M. (1988). Rozwój psychiczny człowieka w ciagu życia. Zagadnienia teoretyczne i metodologiczne. Warszawa: Państwowe Wydawnictwo Naukowe. 


\title{
SOURCES CONDITIONING THE TYPE OF RELATIONSHIP BETWEEN A FATHER AND CHILD. RESEARCH REPORT
}

\begin{abstract}
The article is a part of a research project "Paternal attitudes in rural environment". It is devoted to its narrow fragment about the sources conditioning the type of relationship between a father and a child. Qualitative analysis of the collected research material, which precedes the theoretical introduction, provides current knowledge about the role of the father's family and his inner circle (colleagues and relatives) in fulfilling his own parenthood. The qualitative analysis distinguished three different types of families from which the surveyed men came from as well as the behaviours of fathers towards the children and other family members corresponding to these family types. The research results also showed that most of the interviewees do not follow the patterns of paternal behaviour in their immediate living environment.
\end{abstract}

Keywords: father, child, family, care, upbringing/education.

Lukasz Bartosiak - doktor, absolwent Wydziału Pedagogicznego Uniwersytetu Warszawskiego - nauczyciel, pedagog, muzyk. Obszar jego zainteresowań badawczych koncentruje się wokół problematyki rodziny, w szczególności dotyczy osoby ojca, jego postaw i udziału w procesie opieki i wychowania dziecka. Adres do korespondencji: ul. Osiedlowa 3, 09-533 Słubice. Adres e-mailowy: music84@wp.pl. 